\title{
Preservice teachers' perception of longitudinal child development field coursework at a university-affiliated teaching school
}

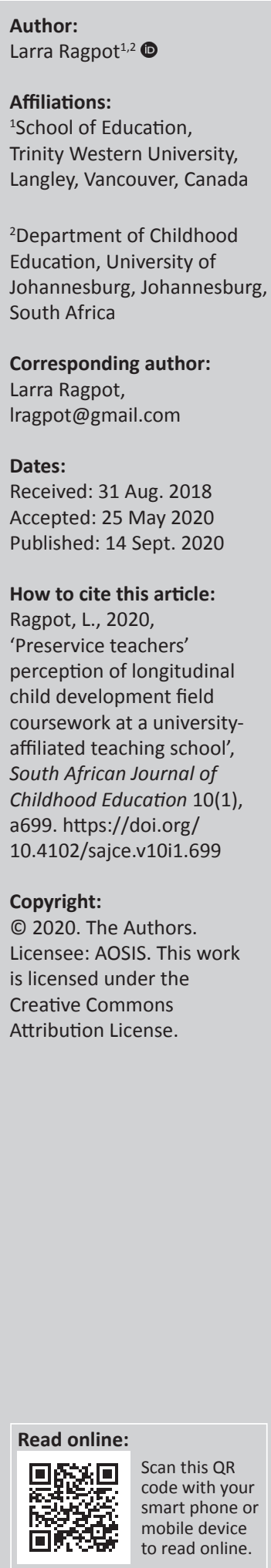

Background: Most field coursework in teacher education (TE) programmes do not incorporate extended in situ interaction with individual children in a classroom. Furthermore, child development theory (from coursework) is not taught in tandem with students' extended periods of practicum placement in schools.

Aim: This study sought to determine preservice teachers' perception of their longitudinal study of children's development and learning in a clinical setting at a university-affiliated teaching school.

Setting: This study focusses on two undergraduate primary school TE programmes at an urban university in Johannesburg, South Africa. These programmes incorporate six semester courses on child development with extended clinical field experience at a teaching school on campus. Each student teacher follows a particular child's development and learning over four years of their undergraduate coursework.

Methods: This was a qualitative descriptive study with some cross-sectional data. Data were collected from 120 undergraduate students, by using anonymous questionnaires and four focus group interviews.

Results: Students reported that they had gained in-depth learning of child development during their longitudinal pairing with an individual child and that assigned observation activities had taught them to recognise, and support, nuanced differences in a child's learning.

Conclusion: Students regard their longitudinal interaction and learning in the clinical setting positively. Future research should focus on the long-term value of the clinical model with insights from students who have graduated from the programme and are in the teaching profession.

Keywords: preservice teacher education; student teachers' clinical field experience; child development and learning; teaching school; South Africa.

\section{Introduction}

This research focusses on preservice student teachers' opinion of their longitudinal learning of child development in their initial primary school teacher education (TE) qualification. This qualification predilects practicum application of theoretical knowledge, as well as an in-depth learning of child development in theory and clinical field coursework during their 4-year undergraduate studies. This research is based on a programme, which takes a very specific stance towards the design and execution of its initial teacher preparation: (1) the necessity of extended meaningful and well-supervised clinical field experiences; and (2) ensuring that child development is at the crux of the programme and taught in such a way that the student teacher can form constant connections between theoretical viewpoints presented in lectures and practical application in clinical classroom settings.

The idea that preservice teachers' university coursework and clinical field experience at schools and in classrooms should be done in tandem, is not new (Kwenda, Adendorff \& Mosito 2017). Many teacher educators argue that few experiences are more important in the preservice teacher's training than early field experience (American Association of Colleges for Teacher Education [AACTE] 2012; Hollins 2015). In field experience, student teachers have the opportunity to apply or 'test' what they have learnt in coursework in practice (National Council for Accreditation of Teacher Education [NCATE] 2010). Despite this argument, the fact that theory learnt in coursework 
has largely been divorced from the real challenges of classroom teaching has a long history globally (Childs, Edwards \& McNicholl 2013) and locally in South Africa (Gravett, Petersen \& Petker 2014). The theory-practice gap is well documented (Allen 2011; Roth Mavin \& Dekker 2014). Many researchers and teacher educators are of the opinion that the disconnect between theory and practice (praxis) persists because there are clashes between conceptual stances about teaching or learning and the implementation of pedagogical practices within classroom settings (Gelfuso, Dennis \& Parker 2015; Zeichner \& Bier 2015). DarlingHammond (2009) succinctly summarises the clinical dilemma of practice-based TE as follows (Darling-Hammond 2009):

Often, the clinical side of teacher education has been fairly haphazard, depending on the idiosyncrasies of loosely selected placements with little guidance about what happens in them and little connection to university work. (p. 11)

It is thus that the call for extended, coherent and relevant clinical experiences in preservice TE programmes is becoming more pronounced (Meyer 2016). DarlingHammond (2009) notes that field experiences must be reconceptualised to become the richest component of preservice teachers' journeys towards learning how to teach. The NCATE (2010) used the phrase that we need to 'turn teacher preparation upside down' and put field or clinical experiences at the core of TE efforts (AACTE 2012). Teacher educators need to conceptualise 'innovative and effective ways to engage preservice teachers in these (clinical) experiences' (Meyer 2016). These field experiences should ideally support preservice student teachers' critical reflection of children's learning and development and pedagogical approaches that support all children's progression (Valencia et al. 2009).

In addition to well-placed, structured and mentored field experiences, preservice teachers should also have a thorough knowledge of child development. If teachers know how children learn and develop, they will know when and how children in their classes are learning and when not. They will, furthermore, be better prepared to intervene when learning targets are not reached sufficiently. The necessity for teachers to have comprehensive knowledge of child development to support optimal teaching has been argued since the previous century. In 1996, in a report to the United States government, Katz (1996) highlights the unequivocal voice of all whom are participating in teaching to show the possession of a thorough knowledge of child development' (Katz 1996:3). In South Africa, the Department of Higher Education and Training (DHET) guidelines call for primary school teachers who are knowledgeable on childhood learning and development (DHET 2010), and it is therefore important to include courses on childhood development in teacher preparation programmes (Korthagen, Loughran \& Russell 2006). However, Ragpot (2017) argues that it is not only important that TE programes should include childhood development courses, which many of them do (Korthagen et al. 2006; NICHD \& NCATE 2006; Oduolowu 2009), but equally important is where and how these courses are presented within the overall TE programme.

It is against this background that a unique TE programme has been designed that affords preservice student teachers an in-depth study of child development over six semester courses. In combination, the student teachers are given constant interaction with children at a university-affiliated teaching school and guided by trained mentor-teachers in the classroom setting. This model of TE further allows the preservice student teachers to 'test' ideas in a clinical setting which were taught about child development in theory during lectures. Whether this in-depth study of a child's development and learning is valuable to the student teacher in the programme has not been formally investigated and leads to the necessity for the current study.

\section{Literature review}

The importance of clinical field coursework in preservice TE is nothing new. In fact since Dewy started the first 'lab-schools' 150 years ago (AACTE 2012), some aspect of practicum work in a classroom at a school has always been part of preservice teachers' professional development (Zeichner 2010a). Numerous studies report on the benefit to the future teacher, if their preservice TE programme included well-supervised clinical experience (Freeman 2010) and even better if the clinical experience is conducted jointly with coursework (Darling-Hammond 2006; Zeichner 2010b). Benefits include: the student teacher's ability to better connect ideas proposed in coursework theory to clinical practice; they become more at ease with the processes of teaching in the classroom; and they demonstrate and represent what they are learning in practice (Hammerness et al. 2005). What the aforementioned asks from a TE programme is careful consideration of the duration of the field coursework, the school environment where the student teacher is placed (thus context of field coursework), with whom the student teacher is placed (mentorship), and lastly the importance of a field coursework programme, which is purposefully associated with specific theory discussed in the university lecture hall (cross-articulation of theory and practice).

Teacher preparation worldwide follows different approaches and programme structures to incorporate field coursework in TE programmes. Since the previous century it has been argued that some programmes are very focussed on academic content, whereas other professionally based programmes focus less on academic theory and more on lesson preparation and classroom practice (Feiman-Nemser 1990). The gold standard would be to have both academic focus and professional development in balance, as exemplified in the Finnish TE programmes.

Preservice TE students in Finland spend considerable time in field coursework in university-affiliated teaching schools. An example is the field coursework in the Department of Education at the University of Helsinki, in Finland, which transpires in two teacher training schools: Normal Lyceum 
of Helsinki and Viikki Teacher Training School (Dickinson \& Silvenionnen 2017). Field coursework is supervised by 130 teachers who act as both teachers of children in the school and mentors for 340 student teachers. In their teacher training year, student teachers spend three days per week at the school where they observe students and mentor teachers and analyse lessons. Constant connections are made between theory and clinical field coursework during student teachers' observation of 44 lessons, participation in 24 mentor-led supervision sessions and teaching of 17 lessons of 75 minutes each (Dickinson \& Silvenionnen 2017).

Elsewhere in Europe, in England, all initial TE programmes include at least 24 weeks spent in schools, with experience in at least two school or college settings. University- and schoolled providers are subject to an inspection cycle of not only the student teachers, but also those who have graduated from programmes and are in their initial years of teaching (Dickinson \& Silvenionnen 2017).

In the United States of America, there are some TE colleges which have affiliated schools on university campuses. These 'lab-schools' such as the Bank Street College of Education's 'Bank Street School for Children' (https:// school.bankstreet.edu/) in New York City and the University of Minnesota's 'Shirley G Moore Lab School' (https://lab-school.umn.edu/) in Minneapolis provide sites for student teachers to do their clinical field coursework. However, this is not the norm, as most TE programmes in the United States of America form partnerships with schools in proximity to the university where student teachers are placed with mentor or host teachers (Regional Educational Laboratory [REL] 2016). These teachers mostly volunteer to 'host' student teachers and have not necessarily undergone any form of formal mentorship training. Some students thus have exemplary field work encounters where others report less favourable experiences (Freeman 2010). As several studies reveal a relationship between student teachers' practical experience and their future retention in teaching (Whitener et al. 1997), it is crucial for student teachers to have positive meaningful encounters in a classroom where they learn the profession from a constructive role model. In the AACTE (2012) report to provincial governments in the United States of America, it is strongly recommended that TE programmes and school districts should cooperatively design and supervise conducive clinical practice partnerships. In these associations, 'mentors, clinical teachers, and clinical faculty should ensure that internshipstyle preparation incorporates advances in the disciplines, teaching and learning, and technology' (AACTE 2012:2).

Even though many studies point to the importance of students to spend extended time in schools, it is crucial to also keep in mind that the place of field coursework is just as important.

Practicum sites or schools could either benefit or be extremely detrimental to the education of the student teacher. Schools thus need to be exemplary and model the type of practice that the TE programme could endorse. This can only happen if there is strong collaboration between TE programmes and the schools where student teachers are placed (REL 2016). The risk of disconnected field experiences is that the student teacher will replicate the status quo of a school they enter, rather than deliberating the full range of teaching approaches and possibilities available (Letts 2013). Student teachers will also have inadequate examples of how to adjust instructional approaches to meet diverse children's needs (REL 2016). Another risk of poor or disconnected field experiences is teacher retention. Whitener et al. (1997) reported on national data in the United States of America, where TE candidates with adequate clinical coursework experience were twice as likely to stay past the first year of teaching as those who have not had such experience. Novice teachers also claim that inadequate field coursework experiences left them feeling less confident and competent in their abilities to teach (Humphrey, Wechsler \& Hough 2008).

Added to the importance placed on sites or schools where field coursework is conducted, there is a call for quality in mentorship by the hosting teacher with whom the student teacher engages during practicum placement (AACTE 2012). A knowledgeable mentor teacher engenders opportunities for student teachers to reflect upon, and develop critical lenses on, teaching practices (Zeichner \& Bier 2015). The way mentorship between mentor and mentee is conducted differs vastly across TE programmes. In some programmes, mentorship happens in an ad hoc manner with few prescriptions (Letts 2013). In others, mentorship is highly structured and hosting teachers undergo formalised mentorship training - for example, at the University of Johannesburg's Funda UJabule universityaffiliated teaching school (University of Johannesburg 2020a) and similarly at the University of Helsinki where all mentor teachers undergo continuous training (Dickinson \& Silvenionnen 2017).

Hellsten, Prytula and Ebanks (2009) note that many mentorship programmes unconsciously draw on the apprenticeship model where a protégé (student teacher) receives knowledge and skills from a master (host teacher). Alternatively, Anderson and Shannon (1988, in Hellsten et al. 2009:707) define the functions of educational mentoring as 'teaching, sponsoring, encouraging, counselling, and befriending'. Feiman-Nemser (2001:17) propositions 'educative mentoring', which comprises emotional support (where the mentor creates a secure relationship and environment for the student teacher) and professional support founded on constructions of how teachers learn. Whichever the model of mentorship that a TE programme adopts, there is no doubt that a mentor who provides a positive role model for the student teacher is crucial to successful field coursework. In fact, Zeichner (2010a) asserts that the crucial elements of professional practice can only be learnt in the context of a classroom under the guidance of a strong mentor. 
Even though aspects of clinical field coursework in general have been researched at length, clinical coursework related to child development, in particular, does not seem to be represented well in the literature. It is known from numerous studies that student teachers develop a wider understanding and are better able to do application of ideas introduced in theoretical university coursework, when they are concurrently participating in field coursework experiences (DarlingHammond 2006; Zeichner 2010a). However, these studies focus more on lesson preparation and classroom management and less on child development in particular (Ragpot 2017). One reason for this might be that most child development courses are delivered by faculty outside of the schools of education, or at least outside of the professional development of teachers. In these courses, the student teacher has no or little interaction, with actual children whilst learning about their development and learning in academic coursework (Ragpot 2017). In this way, cross-articulation of theory and practical observation of the theory, as demonstrated by children's day-to-day classroom interaction, are very little. Also, as Ragpot (2017) asserts child development courses are often taught by faculty from departments of psychology, and little reference to the child's behaviour in class is made. Whether this is because faculty have little or no classroom experience (as they are typically not school teachers) or whether they are more focussed on academic theory, is not clear from the literature.

In summary, the literature highlights that: there is a need for more field coursework in TE programmes as student teachers benefit from continuous and prolonged placement in classrooms (AACTE 2012); it is important that TE programmes work collaboratively with schools where students do their field coursework to ensure quality of experiences and robust learning encounters with a knowledgeable mentor (REL 2016); that theoretical courses should be delivered jointly with field experience coursework (Darling-Hammond, Chung \& Frelow 2002); and that there is a need for child development field coursework in TE programmes where students can observe child development first hand (Ragpot 2017).

\section{Context of the study}

The context of the TE programme reported in this study is the only TE programme in South Africa where preservice students conduct their practicum field experience at a university-affiliated teaching school (Funda UJabule School) on one of the university's campuses (University of Johannesburg 2020a). Each student in the program is also assigned a specific child in the teaching school who they observe and 'work with' during their field work in the school. What makes the programme unique is that each preservice teacher is paired with a specific child whom they follow in observations and work with in course-assigned tasks on child development and learning, over the 4-year period of their initial TE qualification - a model for which the author could not find a counterpart, internationally.

\section{Child development coursework in a unique preservice primary school teacher education programme}

The University of Johannesburg has two primary school undergraduate teacher qualification programmes, into which it accepts on average a cohort of 120 students per programme, per year (University of Johannesburg 2020b), thus a total of 240 students per annum. Completion of a 4-year degree in either foundation phase ${ }^{1}$ (FP) or intermediate phase ${ }^{2}$ (IP) teaching qualifies the graduate to teach in a primary school in South Africa (University of Johannesburg 2020b). The programmes are unique as it is the only primary school teacher qualification in South Africa where preservice student teachers do practicum (or clinical field work) during each semester of their 4-year undergraduate degree.

The programme contains a typical mix of methodology and academic courses found in initial teacher preparation programmes, but is furthermore unique (certainly in the South African context) in that the students' coursework include an in-depth study of child development which is taught by education professors within the department of Childhood Education (University of Johannesburg $2020 \mathrm{~b}$ ) - a strength of the programme highlighted by Ragpot (2017). The programme was designed in this manner to address a shortcoming identified in pre service TE programmes where child development is taught by faculty from departments outside of schools of education, who do not always relate theoretical course content to classroom practice (NCATE 2010).

In the specific TE programmes of the study, the primary purpose of the child development coursework is to introduce the preservice teacher to different aspects of child development (labelled 'Education Studies') over six semester courses from the first to the third year of their undergraduate degree programme as outlined in the faculty of education undergraduate programmes (University of Johannesburg 2020b). Table 1 shows an overview of these courses, their main focus (purpose) and the associated tasks the students do with their assigned child in the specific course (each student is assigned a specific child in the school to observe and 'work with' according to model of practicum placement [Ragpot 2017]).

This table is a summary of the purpose and assessment outlines for the BEd programme in foundation phase and intermediate phase teaching (University of Johannesburg 2020b).

The students do their field or clinical observation tasks over the first 3 years of a 4-year undergraduate initial teacher

1.Foundation phase (FP) is equivalent to elementary school and includes Grades $R$ (kindergarten) to Grade 3 (Basel 2016).

2.Intermediate phase (IP) is equivalent to middle school and includes Grades 4-6 and could also include the first year of senior phase (Grade 7) in some instances, where it is then referred to as Intersen phase. Intermediate phase students are student teachers who are preparing to teach in the intermediate phase (plus Grade 7) in the future (Basel 2016). 
TABLE 1: The main focus and tasks in the child development coursework.

\begin{tabular}{ll}
\hline Year & Course \\
\hline Year 1: & $\begin{array}{l}\text { General introduction } \\
\text { Semester } 1\end{array}$ \\
& $\begin{array}{l}\text { to childhood } \\
\text { development }\end{array}$ \\
Year 1: & $\begin{array}{l}\text { Physical and brain } \\
\text { development }\end{array}$
\end{tabular}

Semester 2 development

$\begin{array}{ll}\text { Year 2: } & \text { Cognitive } \\ \text { Semester } 1 & \text { development and } \\ & \text { learning }\end{array}$

This course has a general introductory focus on child development. The child's general holistic development is investigated from a systemic stance. Understanding the young child and his or her world from different theoretical points of view takes foreground.

This module focusses on obtaining a holistic understanding of the child's physical developmental milestones, brain development and plasticity and the different aspects pertaining to motor development in children. Typical childhood illnesses are also discussed in brief.

The main focus is an integrated understanding of different theories of childhood cognitive development and learning. The core of the course is getting to know and understand a young child's developing mind. Various theories are scrutinised from an educational perspective.

\section{Year 2: Emotional and social Semester 2 development}

$\begin{array}{ll}\text { Year 3: } & \begin{array}{l}\text { Language } \\ \text { Semester } 1\end{array} \\ \text { development }\end{array}$

$\begin{array}{ll}\text { Year 3: } & \text { Barriers to learning } \\ \text { Semester } 2 & \text { and development }\end{array}$

The purpose of this module is to guide a student in developing an understanding of childhood social and emotional development from birth to middle childhood, and to enable the student to support children's socio-emotional development. Emotional, social and moral development of the child in school, family and community is the focus of the module.

The primary purpose of this module is to introduce the student teacher to language and literacy development during the

foundation or intermediate phase. This includes obtaining a holistic understanding of how a child's language and literacy skills develop.

The purpose of this module is to provide the student teacher with an overview of barriers to learning and development as well as the practical support given to children with barriers to learning and development.
devactical support
Brief summary of the observation task at Funda UJabule Teaching School

The student teacher is encouraged to have initial conversations with the child focussed on getting to know the child and establishing rapport. The first observation task is based on observation skills in research and is based on teacher action zones in terms of the assigned child.

The student use a perceptual development checklist to measure different aspects of the child's gross and fine motor skills and visual motor integration. Difficulties are identified and discussed with the mentor teacher. Possible interventions are suggested.

Students investigate Piaget's (Piaget, Gruber, \& Vonèche 1977) notion of stage general cognitive development to their assigned child. The student teacher sees how many characteristics pertaining to the specific age, the child exemplifies and whether the child is developing age appropriately according to Piaget's (Piaget et al. 1977) stage general theory. Lastly, the according to Piaget's (Piaget et al. 1977) stage general theory. Lastly, the
student teacher identifies if the child needs any support and if so what student teacher identifies if the child needs any supp
possible support strategies he or she would suggest.

Students are required to do a case analysis of their assigned child's emotional and social systems according to Erickson's (Salkind 2005) psychosocial theory. Each student teacher also participates in a community engagement activity where they prepare an anti-bullying community engagement activity where they prepare an anti-bullying
awareness campaign for the assigned child's class. The focus is on what awareness campaign for the assigned child's class.
to do when a child or a friend or peer is bullied.

An expressive and receptive language checklist is used to identify how well the assigned child has developed his or her expressive and receptive

language abilities. Students are asked to test the child's various abilities and

then to provide support strategies for the children who display difficulties.

The observation task focusses on childhood attentional difficulties. Each student teacher is expected to screen their assigned child for attention deficit hyperactivity disorder (ADHD), discuss the results of the instruments and give possible recommendations based on the results.

Source: University of Johannesburg, 2020b, Faculty of education undergraduate programmes 2021, viewed 05 May 2020, from https://www.uj.ac.za/studyatUJ/sec/Documents/ Undergraduatebrochure.pdf.

qualification in the university-affiliated teaching school. In the fourth year of the qualification, the students visit the school only for a short period for observation; the rest of the clinical field work is completed in other schools of placement in areas surrounding the university. Each student teacher is assigned a specific child in their first year of study - thus one Grade $\mathrm{R}$ (kindergarten) child is assigned to one FP student teacher and one child in Grade 4 is assigned to a student teacher in the IP - whom they 'follow' four years. The students spend time in the school during practicum in the classroom observing their assigned child from the first year to the fourth year. In the first three years of study, the observations are closely linked to the child development coursework. In the fourth year, the interaction is more general when the students spend time at the teaching school. This is because in this university's programmes the students spend 18 weeks dispersed throughout their fourth year in schools off campus where they do clinical field work and teaching practicum. They have less time in their fourth year to spend with their assigned child, but still get some time for occasional interaction.

\section{Student teacher and child pairing in the clinical field experience setting}

The students' field coursework at the teaching school follows a very specific structure of placement. For context to the study, a short description of the student teacher placement process is necessary.

The Funda UJabule teaching school on the university campus has two classes per grade with 30-35 children per class from Grade R (kindergarten) to Grade 7 (University of Johannesburg 2020a). Students spend time in the classes and act as observers or as teacher assistants. The students' clinical field experience for their child development coursework at the teaching school is divided into two 4-week cycles in the first semester and two 4-week cycles in the second semester. Two groups of between 12 and 16 students spend time in the school per cycle in the FP and two groups of similar number of students in the IP. One group is allocated to an isiZulu ${ }^{3}$ language speaking class and one group to a Sesotho ${ }^{4}$ speaking class. Each student is paired with a specific child in the class (Ragpot 2017). This pairing of a child to a preservice student teacher follows a random allocation by a practicum coordinator at the school. Table 2 shows the number of days each student teacher spends at the school to focus on aspects of child development and learning with their assigned child.

Added to these days the students spend additional time at the teaching school for other field coursework in the programme, as well as service learning (Petersen \& Petker 2017) and other community service. Their interaction with the assigned child thus incorporates a wider range of activities, such as sporting days, gardening and other community projects and not just the specific time allocated in class for child development (Education Studies).

It is within this field coursework context that student teachers' perception of the model of clinical field experience (where they are being paired with a specific child and observing and documenting the child's development and learning over the course of four years) was investigated. An additional focus was to gather their opinion on the feasibility of the child development theoretical coursework and clinical field experience interface, operationalised in observation and 3.Zulu or isizulu is a Southern Bantu language of the Nguni branch spoken in Southern
Africa. This is one of the 11 official languages of learning and instruction in primary education in South Africa. (Ragpot 2017)

4.Sotho or Sesotho is a Southern Bantu language of the Sotho-Tswana group, spoken primarily in South Africa. This is one of the 11 official languages of learning and instruction in primary education in South Africa. (Ragpot 2017) 
TABLE 2: Number of days a student spends in a classroom at the teaching school for child development field coursework.

\begin{tabular}{lccccc}
\hline Time spent at the teaching school in a year & $\begin{array}{c}\text { First } \\
\text { year }\end{array}$ & $\begin{array}{c}\text { Second } \\
\text { year }\end{array}$ & $\begin{array}{c}\text { Third } \\
\text { year }\end{array}$ & $\begin{array}{c}\text { Fourth } \\
\text { year }\end{array}$ \\
\hline $\begin{array}{l}\text { Number of observation days at the teaching } \\
\text { school per week in a cycle }\end{array}$ & 2 & 3 & 3 & 5 \\
$\begin{array}{l}\text { Number of observation days per year } \\
\text { Number of cycles spent at the teaching school }\end{array}$ & 8 & 12 & 12 & 10 \\
$\begin{array}{l}\text { Total number of observation days in } \\
\text { semesters } 1 \text { and 2 }\end{array}$ & 8 & 4 & 4 & 2 \\
Total number of teaching days in semesters 1 and 2 & 0 & 4 & 4 & 0 \\
\hline
\end{tabular}

assigned tasks at the teaching school. The study was thus concerned with the participants' perception of the value they assigned to their interaction with the child.

\section{Method}

This was a qualitative descriptive study with some crosssectional data. The study is situated in two undergraduate primary school TE programmes at an urban university in Johannesburg, South Africa, as delineated in the background discussion of the context of the programme.

\section{Study population and sampling strategy}

Preservice student teachers in the fourth year of their undergraduate teaching qualification were invited to participate in the study. These student teachers have successfully completed the first 3 years of child development courses and associated practicum field coursework at the university-affiliated teaching school. The sampling was thus purposeful as the target group had completed their field coursework at the school, and the sampling was also convenient (Palinkas et al. 2015) as the researcher is a professor in the programme and had access to the students. Two sets of data were collected.

Data from questionnaires were collected during one of the students' final lecture sessions in the fourth year. Participants included $60 \mathrm{FP}$ and $60 \mathrm{IP}$, from a population of 100 (FP) and 105 (IP) student teachers. The lower participation rate could have been attributed to some students not attending lectures on the day of data collection and because participation was voluntary some students opted not to participate. To ensure optimal anonymity, no identifiable characteristics were stipulated on the questionnaire except asking students to indicate whether they belonged to the FP or IP group. This was to ascertain whether results from the two programmes showed significant variance. The gender, ethnicity, age and linguistic background of the respondents are not known, but as the general population of the entire fourth-year cohort is predominantly black and from various cultural groups and language backgrounds, it is safe to assume that this would be the characteristics of the sample as well.

A second set of data were collected via focus group interviews. The participants, who consisted of eight FP and 10 IP students, were purposefully selected via convenience sampling (Palinkas et al. 2015). This is because the researcher had access to the student teachers as they had been placed in schools in the area during their work-integrated practicum sessions, which forms part of their final professional year teacher preparation. All students were asked to give their consent, and their anonymity was ensured. The students were further assured that their feedback would not be viewed as a direct comment on specific course instructors, but critique of the child development field coursework experience in general. As the researcher was not their instructor or lecturer at the time, nor would be in the future of their completion of their degree, researcher bias is not a factor.

\section{Data collection}

Data were gathered by two means, a questionnaire and focus group interviews.

Questionnaire: A self-administered, anonymous questionnaire was designed by the author. With feedback from a small pilot with a group of randomly selected students before the main data were collected, the questions and statements were adapted for clarity. Questions in the questionnaire centred on (1) integration of the child development coursework (Education Studies) with the clinical field experience at the school; (2) the student's perception of the longitudinal interaction with the child at the school; and (3) recommendations for future coursework and the clinical field experience model.

The questionnaire consisted of two sections. In section 1, students were asked to agree (yes) or disagree (no), or give a neutral response (don't know) to the statements (see Table 3 for the content of the statements). In second section of the questionnaire, students were asked to respond in their own words to: their description of an incident or activity where they deemed valuable or memorable during the time that they had spent with their assigned child, and possible recommendations to improve the process and learning encounters of students following a specific child.

Focus group interviews - Four focus group interviews (Morgan 1998) were conducted with small groups of fourth-year students from both the FP and IP groups. The focus group interviews were conducted within a 2-week period after the questionnaires had been completed. Initial guiding questions which centred on the same focus themes as the questionnaire were prepared and with further questions leading onto the participants' answers (DeMarrais 2004). As the focus group interviews were held after the completion and initial analysis of the questionnaires, the researchers had the opportunity to clarify certain comments made by students in the questionnaires, in general. The focus group interviews also afforded the opportunity to ask further questions on possible recommendations student teachers had about the structuring of the fieldwork at the teaching school.

\section{Data analysis}

The data were organised into the three main focus areas of the questions from the questionnaire and the focus group 


\begin{tabular}{|c|c|c|c|c|}
\hline Focus & Statement/question & Yes (\%) & No (\%) & $\begin{array}{c}\text { Don't } \\
\text { know (\%) }\end{array}$ \\
\hline \multirow{4}{*}{$\begin{array}{l}\text { Integration of the child } \\
\text { development coursework } \\
\text { (Education Studies) with the } \\
\text { clinical field experience at the } \\
\text { school }\end{array}$} & The Education studies coursework is well integrated with the practical observation at Funda UJabule school. & 87.5 & 8.3 & 4.2 \\
\hline & $\begin{array}{l}\text { Working with the child in assigned observation activities taught me to recognise different aspects of how } \\
\text { children learn. }\end{array}$ & 83.3 & 14.2 & 2.5 \\
\hline & $\begin{array}{l}\text { The Education studies coursework has prepared me to identify children who experience barriers in their } \\
\text { development and learning. }\end{array}$ & 94.2 & 0.8 & 5.0 \\
\hline & $\begin{array}{l}\text { The Education studies coursework has prepared me to design appropriate interventions for children who } \\
\text { experience barriers in their development and learning. }\end{array}$ & 93.3 & 1.7 & 5.0 \\
\hline \multirow{5}{*}{$\begin{array}{l}\text { The student's perception of the } \\
\text { longitudinal interaction with the } \\
\text { child at the school }\end{array}$} & Following one child over 4 years helped me to learn how children develop. & 71.7 & 20.0 & 8.3 \\
\hline & Following one child helped me to relate what I learnt in the lecture to actual classroom practice. & 67.5 & 26.7 & 5.8 \\
\hline & Working with one child added to my knowledge as a future teacher. & 64.2 & 27.5 & 8.3 \\
\hline & I had enough opportunity/time to engage with the child whom I followed. & 36.6 & 61.7 & 1.7 \\
\hline & I would have liked more interaction with the child. & 83.3 & 10.0 & 6.7 \\
\hline $\begin{array}{l}\text { Recommendations for future } \\
\text { coursework and the clinical field } \\
\text { experience model }\end{array}$ & $\begin{array}{l}\text { I recommend that all teacher education qualifications incorporate this form of training, where students } \\
\text { closely follow a child throughout their training. }\end{array}$ & 80.8 & 9.2 & 10.0 \\
\hline
\end{tabular}

interviews: (1) integration of the child development coursework (Education Studies) with the clinical field experience at the school; (2) the student's perception of the longitudinal interaction with the child at the school; and (3) recommendations for future coursework and the clinical field experience model. Within these main focus areas, the data from the questionnaire were analysed on a frequency table using Microsoft Excel (2016), where the percentages of student's responses to questions were calculated (Table 3). Similarly, students' responses to the open-ended questions from the questionnaire were recorded and transcribed and codes that carried similar meaning were identified and grouped into categories. These categories were organised under the main three main focus areas. The main themes of the study were then abstracted from the organised codes and categories within each of the focus areas.

\section{Ethical consideration}

Each participant gave informed written consent to participate in the study. The Faculty of Education Research Ethics Review Committee at the University of Johannesburg (reference no. Sem 2-2019-019) provided ethical approval. Anonymity and confidentiality were adhered to throughout the study.

\section{Results and discussion}

The objective of this study was to see how students perceived the model of clinical field experience where they are being paired with a specific child and observing and documenting the child's development and learning over the course of 4 years. Results and findings are presented and discussed under the three main focus areas in which the data were organised and analysed.

As a general overview, Table 3 shows the results from section 1 of the questionnaire where the student teachers had to respond to statements with: 'yes' (agree), 'no' (don't agree) and 'don't know'. A discussion of the results, as presented in Table 3, follows in each focus area where data were organised, analysed and findings considered.

\section{Integration of the child development coursework (Education Studies) with the clinical field experience at the school}

From the response to statements in section 1 of the questionnaire (Table 3), the students reported positively on successful integration of child development coursework and clinical field experience at the school; $87.5 \%$ of the students believed that the Education Studies coursework is well integrated with the practical observation at Funda UJabule School, and $83.3 \%$ found that working with the child in assigned observation activities taught them to recognise different aspects of how children learn. They further had positive feedback for their preparation for teaching children with 'barriers to learning' (exceptionalities), from the coursework and field experience, where $94.2 \%$ thought that the coursework has prepared them to identify children who experience barriers in their development and learning, and $93.3 \%$ believed that they had been well prepared to design appropriate interventions for children who experience challenges.

The results from section 2 of the questionnaire and the focus group interviews indicate that the assigned tasks related to theoretical coursework on child development seem to have served their purpose in guiding the student teachers' attention to specific issues relating to child development and learning. They could thus relate what they had learnt in theory in the lecture hall to specific behaviours in the child whom they were assigned to. Student teachers report the following about their experiences: 'I was able to recognise what I had learnt in the classroom (stages of development), I was able to relate in which stage the child was at' and:

' $[D]$ uring the first year we were given an assignment to observe the child and complete a worksheet where they had to perform gross and fine motor movements. This helped me to understand that part of the child's development in front of me.'

Even though student teachers would have liked more interaction with a wider variety of children who were experiencing challenges (see recommendations), they valued the opportunity to follow a child's development over 4 years, which the clinical field experience afforded. They could 
identify different barriers to development and learning that they were learning about in coursework in the child they were assigned to. If their assigned child did not display these barriers, there were other children in the class who did. A student teacher observed:

'When I had to complete the assignment, more specifically the ADHD [Attention deficit hyperactivity disorder] assignment ... the child I observed was quick to speak out of turn and answer incorrectly - I learnt more about childhood ADHD through her.' (T9, female)

The findings from the results in this focus area of the study indicate that the students benefitted from the constant cross-articulation of theoretical coursework into practicable knowledge evident in their classroom encounters with their assigned children. According to the student teachers, this specific theory to practice link as identified as crucial in TE (Darling-Hammond etal. 2002) has thus been adopted successfully by this programme. What is noteworthy is the personalised connection that the students reported on making with their assigned children during this particular longitudinal field coursework experience. Thus, the hypothetical child often referred to in child development coursework discussions (Ragpot 2017) has been replaced by the close encounters with a child with whom the student had built rapport and a relationship (Cantor et al. 2018).

An additional finding is that student teachers valued guidance by a knowledgeable mentor. The need for effective mentorship has been recognised as a primary need in student teacher field coursework (REL 2016). The fact that the mentor teachers in this study are familiar with the theory from theoretical university coursework (as many of them are former students of the programme or have undergone mentorship training), ensures the student teacher is presented with a uniform view of the theory and its practical application in the classroom (Zeichner \& Bier 2015). This practice directly speaks to the call that those involved in field coursework should work together to give the student teacher a unified experience (AACTE 2012).

\section{The student's perception of the longitudinal interaction with the child at the school}

From the response to statements in section 1 of the questionnaire (Table 3), indicated that the student teachers deem the clinical fieldwork with the assigned child a positive learning encounter; $71.1 \%$ believed that following one child helped them understand how children develop. However, the majority $(83.3 \%)$ thought that they would have liked more time to spend with their assigned child, and $61.7 \%$ were of the opinion that they did not have enough time to engage with the child.

Results from the open-ended questions (section 2 of the questionnaire) and the focus group interview show evidence that students believed that the model of being paired with a child over four years afforded them the opportunity to get to know the child. The students reported that following one child over an extended period gives them an in-depth understanding of childhood development. They could also see the child's development first-hand and because they had built rapport with the child, they could interact, and the child also trusted them on a more personal level. A student teacher reported: 'I asked for her activity books, she was so happy to show them to me and even read a story book for me'.

It furthermore afforded to learn about ethical practices with children while they were working with them in the clinical setting under the guidance of a mentor teacher. One student teacher reported the value of having a mentor teacher at hand to ask questions and clarify the child's learning and behaviour:

'When the child had academic difficulties, their class teacher alerted me and explained what problems the child has; this enabled me to understand him better and realise why he was unresponsive with me.'

Learning about children's behaviour went further than just learning of classroom content; students also believed that they were exposed to the child's emotional development and social and peer interactions. This gave them a holistic view of the child in all facets of his or her development. One student teacher reported: 'to observe how children act among their peers helped me to gain a better understanding of socioemotional development'.

The following are some statements from students where they observed the value of the learning experience in the clinical teaching school setting:

'From first year, we have been working with our assigned child. From that experience we are able to observe the way in which they grow, develop and mature according to their level of development.'

and:

'It is good to follow the specific child because you can see the reaction of the child during the lesson and how that changes over time.'

Often students would identify socio-emotional stressors that the child communicated to them during their observation and the child could be supported. A student teacher reported:

'The child was having bad behaviour problems and rebelling against the teacher ... rude in speech ... to teacher and peers. It turned out that she was having family problems and I found this out after talking to her. That made me understand her behaviour more. I will not forget this when I work with my own class one day.'

A student teacher also discussed how she learnt about various filial factors to keep in mind, especially in the South African context where it is the grandmothers who are often the carers of children. The student teacher relates her story:

'There was a time when I attempted to find out why my child was not doing homework and he made me aware that he is staying with his granny and she couldn't read or write. That 
made me aware that social issues have a great impact on the child's learning process.'

From these results, key findings indicate that this unique model of one student teacher observing and interacting with one child longitudinally afforded them integrated understanding of child development across different spheres. This speaks to what Darling-Hammond and colleagues report on for implications for school and classroom practices of 'an emerging consensus about the science of learning and development (SoLD)' (DarlingHammond et al. 2020:97). More specifically, these student teachers in their prolonged direct encounters with specific children learn to build the importance of strong relationships and community, and are exposed to well-scaffolded instruction that supports conceptual understanding, which is viewed from a SoLD perspective as two key principles of practice (Cantor et al. 2018).

\section{Recommendations for future coursework and the clinical field experience model}

The students' responses (Table 3) indicate that they would recommend longitudinal interaction with a child for preservice TE students; $80.8 \%$ of the students recommend that all TE qualifications incorporate this form of training, where students closely follow a child throughout their undergraduate studies.

From responses in section 2 of the questionnaire, and from the focus group interviews, most of the students reported that they would have liked more time to spend with their assigned child. In the words of one participant:

'The university and the school can improve on this process by coming up with a better schedule that will be beneficial to the students, children and teachers at the school. For instance, in between our observations, teaching assistance and delivering lessons, there is almost very little and limited time to follow your assigned child and even conduct our investigations properly. Time for these needs to be accommodated separately.'

Further results indicate that student teachers thought that they should be assigned to more than one child for practical reasons and for more opportunities to learn. The reasons which were given were: (1) practical - if the child is retained in a grade or leaves the school, they would still have access to another child whom they know and with whom they had built rapport. One participant responded: 'I think that students should be allowed to follow at least two children at a time because sometimes children change schools or fail'; (2) more opportunity for learning - participants also believed that observing more than one child at a time will give them the opportunity to compare behaviours and the ways children learn and develop:

'There should be at least two children assigned to each student, as in this way a student teacher can learn to differentiate the learning process between two different children than one.'
Many of the suggestions that students also had involved getting to know the child's parents or carers and doing a home visit: 'It would be better to involve parents so that student teachers can go home and observe instead of hearing from the child on how they live', and:

'Get parents to be more involved with the student teachers as well to make easier for student teachers to understand better the background of the child to improve the quality of the program'.

As one of the main findings that emerged from the study is that students believe that following a child gives them in-depth knowledge of child development and learning, learning about the child's world outside of the school would add an extra dimension to their understanding.

The key findings in terms of the student teachers' recommendations for future coursework and the clinical field experience model are focussed on: more time spent with their assigned children; extended interaction to include more than one assigned child so that they can do comparative work; and a wider sphere of interaction opportunities that goes beyond the classroom and includes the child's family and home context (Cantor et al. 2018).

\section{Conclusion}

This research on how students perceive the longitudinal study of children in this specific programme mostly showed positive feedback. Even though the research just affords initial glimpses into the student teachers' perceptions of the programme and field coursework model, these insights could spark more in-depth research. The study therefore has limitations which could be addressed in future research.

\section{Study limitations}

Although this study could have a potential positive impact on future teacher training, the main weakness was that it relied solely on student teacher feedback. Moreover, the data were collected before students were teaching independently in their own classrooms and might thus be a narrowed perspective under guidance of a mentor. The questionnaire could also be improved in that questions or statements could be paired with a Likert scale, which would afford more indepth quantitative analysis of students' responses.

Extra insight into the success of the student-child pairing could also be gathered from data collected from the course instructors and the mentor classroom teachers at the teaching school. This will afford for more triangulation of data.

\section{Recommendations}

A few recommendations for future study are: the preservice student teachers could be followed into their future careers, and the long-term impact of the study could be evaluated. Also, there could be a comparative study of teachers from this programme and teachers who have not followed this programme. Further research could also be performed to see 
what impact the programme had upon the children who were assigned to the students.

\section{Acknowledgements}

The authors thank the faculty in the Department of Childhood Education and teachers at the Funda UJabule teaching school who are instructors and mentors to students in the programmes mentioned in this study. The authors thank also the participants.

\section{Competing interests}

The authors have declared that no competing interests exist.

\section{Authors' contributions}

L.R. was the sole author on this article.

\section{Funding information}

This research was funded by the National Research Foundation, South Africa and South African Research Chairs Initiative grant (98573).

\section{Data availability statement}

Data sharing is not applicable to this article as no new data were created or analysed in this study.

\section{Disclaimer}

The views and opinions expressed in this article are those of the authors and do not necessarily reflect the official policy or position of any affiliated agency of the authors.

\section{References}

Allen, J.M., 2011, 'How front-end loading contributes to creating and sustaining the theory-practice gap in higher education programs', Asia Pacific Education Review 12, 289-299. https://doi.org/10.1007/s12564-010-9141-x

American Association of Colleges for Teacher Education (AACTE), 2012, Where we stand: Clinical preparation for teachers, Policy brief, viewed 10 May 2020, from https://secure.aacte.org/apps/rl/resource.php?cid=44\&display=all_rl.

Anderson, E.M. \& Shannon, A.L., 1988, 'Toward a conceptualization of mentoring', Journal of Teacher Education 39(1), 38-42. https://doi.org/10.1177/002248718 803900109

Basel, D., 2016, Which teaching programme is right for me?, viewed 05 May 2020 from https://educonnect.co.za/which-teaching-programme-is-right-for-me/.

Cantor, P., Osher, D., Berg, J., Steyer, L. \& Rose, T., 2018, 'Malleability, plasticity, and individuality: How children learn and develop in context', Applied Developmental Science 23(4), 307-337. https://doi.org/10.1080/10888691.20 17.1398649

Childs, A., Edwards, A. \& McNichol, J.L., 2013, 'Developing a multi-layered system of distributed expertise: What does cultural historical theory bring to understandings of workplace learning in school university partnerships?', in O. McNamara, J. Murray \& M. Jones (eds.), Workplace learning in teacher education: International practice and policy, pp. 29-45, Springer, New York, NY.

Darling-Hammond, L., 2009, The flat world and education: How America's commitment to equity will determine our future, Teachers College Press, New York, NY.

Darling-Hammond, L., 2010, 'Teacher education and the American future', Journal of Teacher Education 61(1-2), 35-47, viewed 26 August 2018, from https://jte. sagepub.com/cgi/content/abstract/61/1-2/35.

Darling-Hammond, L., Chung, R. \& Frelow, F., 2002, 'Variation in teacher preparation: How well do different pathways prepare teachers to teach?', Journal of Teacher Education 53(4), 286-302, viewed 10 May 2020, from https://www researchgate. net/publication/251508542_Variation_in_Teacher_Preparation_How_Well_Do_ Different_Pathways_Prepare_Teachers_to_Teach.
Darling-Hammond, L., Flook, L., Cook-Harvey, C., Barron, B. \& Osher, D., 2020 'Implications for educational practice of the science of learning and development', Applied Development Science 24(2), 97-140. https://doi.org/10.1080/10888691. 2018.1537791

DeMarrais, K., 2004, 'Qualitative interview studies: Learning through experience', in K. DeMarrais \& S.D. Lapan (eds.), Foundations for research. Methods of inquiry in education and the social sciences, pp. 51-68, Erlbaum, Mahwah, NJ.

Department of Higher Education and Training (DHET), 2010, Draft policy on the minimum requirements for teacher education qualifications aligned with the higher education qualifications framework, DHET, Pretoria.

Dickinson, P.R. \& Silvennionen, J.I., 2017, 'Comparing secondary initial teacher education in England and Finland: Learning together', in T.A. Trippestad, A. Swennen \& T. Werler (eds.), The struggle for teacher education: International A. Swennen \& T. Werler (eds.), The struggle for teacher education: Internatives on governance and reforms, pp. 75-97, T\&T Clark, London.
perspective

Feiman-Nemser, R., 1990, 'Teacher preparation: Structural and conceptual alternatives', in W.R. Houston (ed.), Handbook for research on teacher education, Macmillan, New York, NY, viewed 20 July 2020, from http://education.msu.edu/ncrtl/pdfs/ New York, NY, viewed $20 \mathrm{~J}$
ncrtl/issuepapers/ip895.pdf

Freeman, G., 2010, 'Strategies for successful early field experiences in a teacher education program', Southeastern Regional Association of Teacher Educators education program', Southeast
(SRATE) Journal 19(1), 15-21.

Gelfuso, A., Dennis, D.V. \& Parker, A., 2015, 'Turning teacher education upside down: Enacting the inversion of teacher preparation through the symbiotic relationship of theory and practice', Professional Educator 39(2), viewed 26 August 2018, from https://eric.ed.gov/?id=EJ1084835

Gravett, S., Petersen, N. \& Petker, G., 2014, 'Integrating foundation phase teacher education with a "teaching school" at the University of Johannesburg', Education as Change 18(suppl 1), 107-119. https://doi.org/10.1080/16823206.2013.877357

Hammerness, K., Darling-Hammond, L., Bransford, J., Berliner, D., Cochran-Smith, M. McDonald, M. et al., 2005, 'How teachers learn and develop', in L. Darling-Hammond \& J. Bransford (eds.), Preparing teachers for a changing world: What teachers should learn and be able to do, pp. 385-389, Jossey-Bass, San Francisco, CA.

Hellsten, L.M., Prytula, M.P. \& Ebanks, A., 2009, 'Teacher induction: Exploring beginning teacher mentorship', Canadian Journal of Education 32(4), 703-733.

Hollins, E.R. (ed.), 2015, Rethinking field experiences in preservice teacher preparation, Routledge, New York, NY.

Humphrey, D.C., Wechsler, M.E. \& Hough, H.J., 2008, 'Characteristics of effective alternative teacher certification programs', Teachers College Record 110(1), 1-63, viewed 10 May 2020, from https://www.semanticscholar.org/paper/Characteristicsof-effective-alternative-teacher-Humphrey-Wechsler/1b70d4ea840665021d831fbc 635ab9b05a44e6b3.

Katz, L.G., 1996, 'Child development knowledge and teacher preparation: Confronting assumptions', Early Childhood Research Quarterly 11(2), 135-146. https://doi. org/10.1016/S0885-2006(96)90002-2

Korthagen, F., 2017, 'Inconvenient truths about teacher learning: Towards professional development 3.0', Teachers and Teaching 23(4), 387-405. https://doi. org/10.1016/j.tate.2006.04.022

Korthagen, F., Loughran, J. \& Russell, T., 2006, 'Developing fundamental principles for teacher education programs and practices', Teaching and Teacher Education 22(8), 1020-1041. https://doi.org/10.1016/j.tate.2006.04.022

Kwenda, C., Adendorff, S. \& Mosito, C., 2017, 'Student-teachers' understanding of the role of theory in their practice', Journal of Education (University of Kwazulu-Natal) 69, 139-159.

Letts, W.J., 2013, 'Working with practice communities to conduct teacher education: An international endeavour', in J. Higgs, D. Sheehan, J. Baldry Currens, W. Letts \& G.M. Jensen (eds.), Realising exemplary practice based education, pp. 111-118, Sense Publishers, Rotterdam.
S.M. Jensen (eds.), Realising

Meyer, S.J., 2016, Understanding field experiences in traditional teacher preparation programs in Missouri (REL 2016-145), U.S. Department of Education, Institute of Education Sciences, National Center for Education Evaluation and Regional Assistance, Regional Educational Laboratory Central, Washington, DC, viewed 26 August 2018, from https://ies.ed.gov/ncee/edlabs/regions/central/pdf/REL 26 August 2016145.pdf.

Microsoft Corporation, 2016, Microsoft Excel, viewed 15 May 2020, from https:// office.microsoft.com/excel.

Morgan, D., 1998, The focus group guidebook, Sage, Thousand Oaks, CA.

National Council for Accreditation of Teacher Education (NCATE), 2010, Transforming teacher education through clinical practice: A national strategy to prepare effective teachers, Author, Washington, DC, viewed 26 August 2018, from https://eric. ed.gov/?id=EJ919045.

National Institute of Child Health and Human Development (NICHD) \& The National Council for the Accreditation of Teacher Education (NCATE), 2006, Child and adolescence development research and teacher education: Evidence-based pedagogy, policy, and practice, Summary of Roundtable Meetings, viewed pedagogy, policy, and practice, Summary of Roundtable Meetings, viewed
12 December 2010, from https://www.nichd.nih.gov/publications/pubs/child adol_dev_teacher_ed.pdf.

Oduolowu, E., 2009, 'An overview of collaborative teacher preparation programme in a Nigerian University', European Journal of Social Sciences 9(2), 329-337, viewed 25 January 2011, from https://www.eurojournals.com/ejss_9_2_14.pdf.

Palinkas, L.A., Horwitz, S.M., Green, C.A., Wisdom, J.P., Duan, N. \& Hoagwood, K. 2015, 'Purposeful sampling for qualitative data collection and analysis in mixed method implementation research', Science+Business Media 42(5), 533-544. https://doi.org/10.1007/s10488-013-0528-y 
Petersen, N. \& Petker, G., 2017, 'Teacher education students' struggles with group work in service learning', South African Journal of Childhood Education 7(1), a479, viewed 16 May 2020, from https://sajce.co.za/index.php/sajce/article/view/479/486.

Piaget, J., Gruber, H.E. \& Vonèche, J.J., 1977, The essential Piaget, Basic Books, New York, NY.

Ragpot, L., 2017, 'The essence of future teaching and learning in the foundation phase: Knowing the developing mind of the child in the theory practice interface' South African Journal of Childhood Education, SAJCE 7(1), a501. https://doi. org/10.4102/sajce.v7i1.501

Regional Educational Laboratory (REL) Central Webinar, 10 November 2016, Field experiences in traditional teacher preparation programs: An overview from a study in Moussiri, viewed 25 August 2018, from https://www.youtube.com/ watch?v=GHsMwtkX56c\&t=491s.

Roth, W.M., Mavin, T. \& Dekker, S., 2014, 'The theory-practice gap: Epistemology, identity, and education', Education and Training 56(6), 521-536. https://doi org/10.1108/ET-11-2012-0117

Salkind, N.J., 2005, 'Erikson's stages of psychosocial development', in S.W. Lee (ed.), Encyclopedia of school psychology, Sage Publications, Inc, viewed 15 May 2020, from https://doi.org/10.4135/9781412952491.

University of Johannesburg, 2020a, Funda UJabule School, viewed 16 May 2020, from https://www.uj.ac.za/faculties/facultyofeducation/DepartmentofChildhood Education/Pages/Funda-UJabule-School.aspx.
University of Johannesburg, 2020b, Faculty of education undergraduate programmes 2021, viewed 05 May 2020, from https://www.uj.ac.za/studyatUJ/sec/Documents/ Undergraduate-brochure.pdf.

Valencia, S.W., Martin, S.D., Place, N.A. \& Grossman, P., 2009, 'Complex Interactions in Student Teaching: Lost Opportunities for Learning', Journal of Teacher Education 60(3), 304-322.

Whitener, S.D., Gruber, K.J., Lynch, H., Tingos, K., Perona, M. \& Fondelier, S., 1997 Characteristics of stayers, movers, and leavers: Results from the teacher follow-up survey, 1994-95, U.S. Department of Education, Office of Educational Research and Improvement, Washington, DC, viewed 11 May 2020, from https://nces.ed. gov/pubs97/97450.pdf.

Zeichner, K., 2010a, 'The importance of strong clinical preparation for teachers', presented at a U.S. Congressional Briefing organized by the American Association of Colleges for Teacher Education, Washington, DC, 17 June 2010, viewed 25 August 2018, from https://www.ccte.org/wp-content/pdfs-conferences/ccteconf-2012-fall-zeichner-clinical-preparation.pdf.

Zeichner, K., 2010b, 'Rethinking the connections between campus courses and field experiences in College and University-based teacher education', Journal of Teacher Education 40(1), 1-11, viewed 10 August 2018, from https://www. researchgate.net/publication/249704767.

Zeichner, K. \& Bier, M., 2015, 'Opportunities and pitfalls in the turn toward clinical practice in U.S. teacher education', in E.R. Hollins (ed.), Rethinking field experiences in preservice teacher preparation, pp. 20-46, Routledge, New York, NY. 